\title{
Methodological Developments to the UK Environmental
}

\section{Accounts}

\section{Donna Livesey, Office for National Statistics}

\section{Summary}

This article introduces the methodological developments to be implemented with the publication of the UK Environmental Accounts on 29 June 2011, primarily the implementation of Standard Industrial Classification 2007 (SIC2007) and the continuing review of road transport methodology for the energy consumption and air emissions statistics. The article also previews other developments planned for the next 2-3 years.

\section{Introduction}

In June 2010, ONS launched an open consultation ${ }^{1}$ on the strategy for the UK Environmental Accounts, the responses $^{1}$ to which were later published. Specific points of interest were:

- plans to move from a 6-monthly to an annual publication to refocus resources on developing the accounts,

- priorities for the development programme and the role of UK Environmental Accounts in wider ONSled work on measuring national wellbeing.

This article outlines the developments from this strategy to be implemented in the newly annual publication in June 2011 and provides an update on other planned developments.

\section{Developments to the 2011 UK Environmental Economic Accounts}

\section{Moving to an annual publication}

ONS has moved to publishing the Environmental Accounts once a year, in June. The Environmental Accounts is essentially made up of annual statistics and a significant amount of resource is attached to issuing each publication. By reducing the number of publications each year, this resource has been redirected towards the development programme.

Following the open consultation, users have asked whether a more modular approach might be possible in future, with a rolling programme of small releases each year. It is possible that the new ONS website, 
scheduled for launch on 28 August 2011, may mean that this can be achieved more cost effectively and this will be examined. See the later section on improving accessibility.

\section{Implementation of SIC2007}

The UK Environmental Accounts ${ }^{2}$ present industry breakdowns for several accounts. These are broadly based on Standard Industrial Classification 2003 (SIC2003), but have historically been assigned 'EAcodes', a coding system encompassing 93 industries which can be directly matched with SIC2003 codes. This reflected that for some industries, the Environmental Accounts presented a greater level of detail than for others, for example, the transport industries. Experience shows that this has sometimes hindered the ability of users to interpret the statistics, and importantly, made matching with economic statistics more difficult.

In the 2011 UK Environmental Accounts, the latest industrial classification system, SIC2007 ${ }^{3}$ will be implemented and the opportunity will be taken to move away from the system of EAcodes and utilise the SIC coding system which will improve transparency and accessibility. This section outlines the changes which can be expected.

The accounts for which an industry split is available are:

- Energy consumption

- Air emissions

- Environmental protection expenditure

- Waste

\section{Energy consumption and air emissions}

A programme of work was undertaken in 2010/11 to remap the air and energy accounts from the 93 EAcodes to SIC2007. As part of this programme, led by the data suppliers AEA Technology, the accounts for reference period 2008 (plus historical time series) published in the 2010 UK Environmental Accounts were remapped with no other changes to the methodology and sources so that the processes could be tested and the impact could be fully understood through a quality assurance process with ONS.

The main UK Environmental Accounts publication presents a high level industry breakdown, supported by detailed industry datasets made available on-line. Table 1 illustrates the changes to the high level industry breakdown which will be presented in the 2011 publication, where it can be seen that the main changes are the combination of waste services with electricity, gas and water supply and the provision of more detail on the service industries. 
Table 1 - Changes to the high level industry breakdown with the implementation of SIC2007

\begin{tabular}{|c|c|}
\hline 2010 Publication & 2011 Publication - SIC2007 sections \\
\hline Agriculture & A - Agriculture, Forestry and Fishing \\
\hline Mining and quarrying & B - Mining and quarrying \\
\hline Manufacturing & C - Manufacturing \\
\hline Electricity, gas and water supply & $\begin{array}{l}\text { D, E - Electricity, gas steam and air conditioning } \\
\text { supply, water supply, sewerage, waste management } \\
\text { activities and remediation services }\end{array}$ \\
\hline Construction & F- Construction \\
\hline Wholesale and retail trade & $\begin{array}{l}\text { G - Wholesale and retail trade; repair of motor } \\
\text { vehicles and motorcycles }\end{array}$ \\
\hline Transport and communication & $\begin{array}{l}\mathrm{H}, \mathrm{J} \text { - Transport and storage, information and } \\
\text { communication }\end{array}$ \\
\hline \multirow[t]{3}{*}{ Other business services } & I - Accommodation and food services \\
\hline & K - Financial and insurance activities \\
\hline & $\begin{array}{l}\mathrm{L}, \mathrm{M}, \mathrm{N} \text { - Real estate activities, professional, scientific } \\
\text { and technical activities, administrative and support } \\
\text { services activities }\end{array}$ \\
\hline Public administration & $\begin{array}{l}\text { O - Public administration and defence, compulsory } \\
\text { social security }\end{array}$ \\
\hline \multirow[t]{2}{*}{ Education, health and social work } & P - Education \\
\hline & Q - Human health and social work activities \\
\hline \multirow[t]{2}{*}{ Other services } & $\begin{array}{l}\mathrm{R}, \mathrm{S} \text { - Arts, entertainment and recreation, other } \\
\text { service activities }\end{array}$ \\
\hline & $\begin{array}{l}\text { T - Activities of households as employers, } \\
\text { undifferentiated goods and services }\end{array}$ \\
\hline Households & Consumer expenditure \\
\hline
\end{tabular}


Table 2 - Greenhouse gas emissions in 2008

\begin{tabular}{|c|c|c|c|}
\hline Sector & $\begin{array}{c}\text { Thousand } \\
\text { tonnes }\end{array}$ & Sector & $\begin{array}{l}\text { Thousand } \\
\text { tonnes }\end{array}$ \\
\hline Agriculture & 50336 & Agriculture, forestry \& fishing & 50356 \\
\hline Mining \& quarrying & 25313 & Mining \& quarrying & 25190 \\
\hline Manufacturing & 107112 & Manufacturing & 107546 \\
\hline Electricity, gas and water supply & 192117 & $\begin{array}{l}\text { Electricity, gas, steam \& air conditioning } \\
\text { supply; water supply, sewerage, waste } \\
\text { management activities \& remediation } \\
\text { services }\end{array}$ & 217053 \\
\hline Construction & 10272 & Construction & 10717 \\
\hline Wholesale and retail trade & 18500 & $\begin{array}{l}\text { Wholesale \& retail trade; repair of motor } \\
\text { vehicles \& motorcycles }\end{array}$ & 14434 \\
\hline Transport and communication & 94056 & $\begin{array}{l}\text { Transport \& storage; information \& } \\
\text { communication }\end{array}$ & 94793 \\
\hline \multirow[t]{3}{*}{ Other business services } & 7409 & Accommodation \& food services & 2632 \\
\hline & & Financial \& insurance activities & 710 \\
\hline & & $\begin{array}{l}\text { Real estate activities; professional, scientific } \\
\& \text { technical activities; administrative \& } \\
\text { support service activities }\end{array}$ & 6302 \\
\hline Public administration & 7755 & $\begin{array}{l}\text { Public administration \& defence; } \\
\text { compulsory social security }\end{array}$ & 7577 \\
\hline \multirow[t]{2}{*}{ Education, health and social work } & 9373 & Education & 4685 \\
\hline & & Human health \& social work activities & 5778 \\
\hline \multirow[t]{3}{*}{ Other services } & 27725 & $\begin{array}{l}\text { Arts, entertainment \& recreation; other } \\
\text { service activities }\end{array}$ & 2185 \\
\hline & & $\begin{array}{l}\text { Activities of households as employers; } \\
\text { goods \& services households for own use }\end{array}$ & 397 \\
\hline & & $\begin{array}{l}\text { Activities of extraterritorial organisations \& } \\
\text { bodies }\end{array}$ & 0 \\
\hline Household & 149983 & Consumer expenditure & 149597 \\
\hline Total & 699952 & Total & 699952 \\
\hline
\end{tabular}

Table 2 illustrates the change in distribution of the total greenhouse gas emission in 2008 published in the 2010 UK Environmental Accounts when the SIC2007 breakdown is applied. The table illustrates that the impact at this level is not significant. 
For the air and energy accounts, in addition to the main publication, there is a rich source of data published on the ONS website breaking the headline statistics down by pollutant, source and industry. To date this has been the 93 EA codes but from this year the breakdown will be at SIC2007 2-digit level with the following additional splits which either users have requested or provide better mapping to the economic supply-use tables:

Division 10 - Manufacture of food products - broken down to 3-digit level

Division 11 - Manufacture of beverages - broken down between alcohol and soft drinks

Division 20 - Manufacture of chemicals and chemical products - broken down to 3,4 and 5 digit level

Division 22 - Manufacture of rubber and plastic products - broken down between rubber and plastics

Division 23 - Manufacture of other non-metallic mineral products- broken down to 3,4 and 5 digit level

Division 24 - Manufacture of basic metals- broken down to 3,4 and 5 digit level

Division 25 - Manufacture of fabricated metal products - broken down between metal products and manufacture of weapons and ammunition

Division 30 - Manufacture of other transport equipment - broken down by ships, air and other

Division 33 - Repair and installation of machinery and equipment - broken down by ships, air and other

Division 35 - Electricity, gas, steam and air conditioning supply - an artificial split has been introduced for electricity production to allow the continued presentation of statistics by source of electricity - gas, coal, oil, nuclear, other

Division 49 - Land transport and transport via pipelines - broken down to 3,4 and 5 digit level

Division 65 - Insurance and pension funds - split between insurance and pension funds

Division 68 - Real estate activities - 3-digit split

Division 69 - Legal and accounting activities - 3-digit split

Division 84 - Public administration and defence - defence activities separated out

\section{Environmental protection expenditure and waste}

Environmental protection expenditure and waste accounts are sourced from the Department for Environment, Food and Rural Affairs (Defra) statistics which have been published on an SIC2007 basis for the first time in the last 12 months. These statistics will be presented in the 2011 Environmental Accounts.

The environmental protection expenditure accounts are drawn from a survey for 2008 carried out on behalf of Defra by URS Corporation Ltd $^{4}$. Environmental protection expenditure in specified industries gives figures for spending by the following industries: Mining and quarrying (SIC05-09), Food, beverages and tobacco (10- 
12), Paper and pulp (17), Coke/and refined petroleum(19), Chemicals and pharmaceuticals (20-21), Basic and fabricated metals (24-25), Electricity, gas \& water supply (35-36).

The Defra statistics on general waste arisings depend on a variety sources, the key source being the Survey of Commercial and Industrial Waste Arisings ${ }^{5}$ which was conducted on a SIC2007 basis for the first time for calendar year 2009 reference period.

\section{Environment taxes}

Environmental taxes are presented in two ways in the environmental accounts - by type of tax (e.g. air passenger duty, vehicle excise duty) and by industry. The 2011 UK Environmental Accounts will present taxes by type of tax. The industry split using SIC2007 for the industry split will be implemented in the 2011 UK National Accounts Blue Book, when the necessary economic data becomes available with the supply-use tables reworked on to the new industry classification. It is usual practice for the industry statistics to be updated each year in Blue Book ${ }^{6}$ where the UK Environmental Accounts are presented as a summary chapter.

\section{Energy consumption and air emissions - Review of road transport methodology}

The air and energy accounts are produced for ONS by AEA Technology plc based on data compiled for the National Atmospheric Emissions Inventory (NAEI) ${ }^{7}$ and UK Greenhouse Gas Inventory (GHGI) ${ }^{8}$. Every year a programme of development work is undertaken to optimise the methodologies employed in compiling the accounts. Assessments in previous years have indicated that a number of splits used to apportion road transport source data to more than one industry should be reviewed. The results of this review will be implemented in the 2011 UK Environmental Accounts for the reference period 2009 and years back to 1990.

The assessment considered both the quality of each sectoral split and the magnitude of emissions distributed using the split, with carbon emissions being prioritised above emissions of other pollutants. Splits have been reviewed for petrol cars, diesel cars and LGVs, industrial and commercial combustion of natural gas, articulated and rigid HGVs and diesel off-road vehicles.

The review also recommends longer term developments and these will be detailed in the publication. 


\section{Valuation of UK Continental Shelf oil and gas reserves}

In the past, ONS has published physical and monetary asset accounts for UK Continental Shelf oil and gas reserves. In 2010, the monetary account was suspended pending review as a key data source had been discontinued and over time the estimation process was no longer considered fit for purpose. This review is now complete and a methodological article and first results will be published as part of the 2011 UK Environmental Accounts.

\section{Suspension of accounts}

One of the proposals of the Environmental Accounts Strategy was to suspend three further accounts until they can be reviewed. This will take effect in the 2011 publication and the affected accounts are fish stocks, radioactive waste and the UK water accounts (though the latest development work by Defra on water accounts for England and Wales will continue to be presented).

These accounts were early pilots which have not been updated due to limited resources and discontinuation of source data. The review of the accounts will be scheduled within the context of the implementation of international standards and the development of measures of national well-being. See the section on future planned developments for more detail.

\section{Future planned developments}

Summarised here are a range of developments planned for the UK Environmental Accounts over the next 2-3 years. More details will be published as the development programme progresses but if you have an interest in engaging with any of the projects listed, please get in touch using the contact details below.

\section{Measuring National Well-being}

ONS is developing new measures of national well-being. The aim is that these new measures will cover the quality of life of people in the UK, environmental and sustainability issues, as well as the economic performance of the country. To develop better measures of the nation's well-being ONS asked people what matters most in their lives and what is important for measuring the nation's well-being. The debate is now closed and ONS is analysing the submissions, with a report on the findings of the debate expected in July 2011. The UK Environmental Accounts will play a key role in delivering environmental sustainability measures and a project has been set up, with ONS and DEFRA working together, to deliver such measures. Plans to develop the accounts in response to the national well-being debate findings will be published later this year. 


\section{Implementing UN System of Environmental Economic Accounts (SEEA)}

The United Nations Statistical Commission is seeking to elevate the Handbook of National Accounting: Integrated Environmental and Economic Accounting (SEEA) ${ }^{9}$ to an international statistical standard to operate alongside the System of National Accounts $(S N A)^{10}$. It is anticipated that volume 1 of the revised SEEA will be adopted in February 2012 as the statistical standard for environmental-economic accounting. It will provide an internationally agreed set of recommendations expressed in terms of concepts, definitions, classifications, accounting rules and standard tables in order to obtain international comparability of environmental-economic accounts and related statistics.

ONS has started to assess how the international standard will be applied in the UK, beginning with the first draft chapter made available for global consultation, Chapter 5: Asset Accounts ${ }^{11,}$ which considers both physical and monetary aspects of environmental asset accounting.

ONS is also coordinating the UK response to the global consultation.

\section{European Regulation on Environmental Economic Accounting}

The importance of international comparability and the application of an international standard are highlighted by developments in Europe to adopt a Regulation on Environmental Economic Accounting. To date, European data collection has operated on the basis of shared best practice and the goodwill of national statistics institutes. The provision of key economic statistics is already covered by European Regulation and the adoption of similar legislation stresses the increasing policy importance of the evidence base provided by the environmental economic accounts.

In the first instance, the Regulation will cover air emissions accounts, material flow accounts and environmental taxes, all of which the UK already supplies on a voluntary basis. However, it is widely accepted that the Regulation will be extended over time and ONS will be engaging fully in this international development. 


\section{Measurement of the UK Environmental Goods and Services Sector}

There is a clear requirement in the UK, and internationally, to measure the progress towards a 'green' economy, and within this to understand the contribution of the environmental goods and services sector to the economy and the potential for growth. In December 2010, ONS published an article ${ }^{12}$ introducing the work being taken forward by ONS to measure this sector and discussing the challenges ahead. The feasibility study is due to report in Autumn 2011 when a follow up article will be published.

\section{Improving accessibility}

The new ONS website will be launched on 28 August 2011. The ONS website is the main way people access ONS outputs, including the UK Environmental Accounts, and the focus of development is putting users' needs first. The new website will make it quicker and easier to find information, including better search and navigation facilities and it will be easier to download data and charts.

For the UK Environmental Accounts ONS is taking the opportunity to streamline the on-line material to make it more accessible and present a more coherent picture of the environment and the economy.

\section{UK Statistics Authority (UKSA) Assessment of the UK Environmental Accounts}

This assessment against the Code of Practice for Statistics ${ }^{13}$ and designation against the related 'National Statistics' quality mark, is nearing completion and it is anticipated the UKSA report will be published in Summer 2011. The recommendations of this assessment will be immediately reviewed and plans put in place to deliver on those recommendations.

\section{Conclusion}

A number of developments will be made to the 2011 UK Environmental Accounts but the development programme will continue to move forward reflecting the increasing relevance of the accounts, both in the UK and internationally. More detailed plans will be published later this year, with a supporting timetable, following the publication of the findings of the debate on measuring national well-being. 


\section{Notes}

1. http://www.ons.gov.uk/about/consultations/closed-consultations/consultation-on-the-strategy-forthe-uk-environmental-accounts/index.html

2. http://www.statistics.gov.uk/StatBase/Product.asp?vlnk=3698\&Pos=1\&ColRank=1\&Rank=272

3. http://www.statistics.gov.uk/statbase/Product.asp?vlnk=14012

4. http://www.defra.gov.uk/statistics/environment/environmental-survey/survey-results/

5. http://www.defra.gov.uk/statistics/files/ci-release-10.pdf

6. http://www.statistics.gov.uk/StatBase/Product.asp?vlnk=1143\&Pos=\&ColRank=1\&Rank=272

7. http://naei.defra.gov.uk/

8. http://ghgi.decc.gov.uk/

9. UN System of National Accounts, http://unstats.un.org/unsd/sna1993/toctop.asp

10. UN System of Environmental Economic Accounts, Department of Economic and Social Affairs, Statistics Division, United Nations, http://unstats.un.org/unsd/envaccounting/seearev/

11. http://unstats.un.org/unsd/envaccounting/seearev/chapterList.asp

12. Livesey D (2010), Measuring the environmental goods and services sector, ONS Economic \& Labour Market Review, ISSN: 1751-8334,

http://www.statistics.gov.uk/cci/article.asp?ID=2620\&Pos=1\&ColRank=1\&Rank=1

13. http://www.statisticsauthority.gov.uk/assessment/code-of-practice/index.html

\section{Contact}

Environment.accounts@ons.gsi.gov.uk 